\title{
Variations in liveweight gains, milk yield and composition of Red Sokoto goats fed crop-residue-based supplements in the subhumid zone of Nigeria
}

\author{
B.S. Malau-Aduli ${ }^{\mathrm{b}}$, L.O. Eduvie ${ }^{\mathrm{a}}$, C.A.M. Lakpini ${ }^{\mathrm{a}}$, A.E.O. Malau-Aduli ${ }^{\mathrm{a}, *}$ \\ ${ }^{a}$ National Animal Production Research Institute, Ahmadu Bello University, PMB 1096 Zaria, Nigeria \\ ${ }^{\mathrm{b}}$ Department of Animal Science, Ahmadu Bello University, PMB 1044 Zaria, Nigeria
}

Received 29 July 2002; received in revised form 14 January 2003; accepted 20 January 2003

\begin{abstract}
Variations in weight gain, milk yield, milk composition, nutrient intake and digestibility of Red Sokoto goats supplemented with crop-residue-based rations during the long, dry period were investigated. Ration $\mathrm{A}$, the conventional concentrate ration, was used as the positive control, Rations B and C were the two crop-residue test diets, while Ration D the unsupplemented treatment, was used as the negative control. Each of the supplementation rations was fed at 1 and $2 \%$ of the goat's body weight (designated as 1A, 2A, 1B, 2B and 1C, 2C, respectively). The supplemented group of goats had significantly higher $(P<0.05)$ dry matter $(\mathrm{DM})$ and crude protein $(\mathrm{CP})$ intakes as well as nutrient digestibilities than the unsupplemented groups. DM digestibility improved with supplementation by a range of 4.1-27.9\%, while CP digestibility improved by $17.1-42.2 \%$, the highest value being in does on Ration A. It was evident that supplementation significantly $(P<0.01)$ influenced weight gains and milk yield of dams. Goats on ration $2 \mathrm{C}$ recorded the highest average daily gains of $39.29 \mathrm{~g} /$ day while their counterparts fed rations $1 \mathrm{~B}$ and D lost 28.57 and $92.86 \mathrm{~g} /$ day, respectively. Ration $1 \mathrm{C}$ which comprised mainly of crop residue with much lesser protein levels than the concentrate ration, produced $54 \mathrm{~kg}$ of milk over a 90-day lactation period averaging $0.60 \mathrm{~kg}$ per day. Goats on Ration D had the shortest lactation length of 41 days and the least total and average daily milk yields of 10.2 and $0.25 \mathrm{~kg}$, respectively. Milk from does on ration 2A contained the highest percentages of fat $(6 \%)$, protein $(6.33 \%)$, total solids $(21.85 \%)$ and solids-not-fat $(15.85 \%)$. Milk from goats on ration D ranked least with respect to all parameters studied. It was concluded that the goats made appreciable gains in the long dry season on crop-residue-based diets that compared favourably with the conventional concentrate rations. Ration C fed at $1 \%$ level was a good supplementary feed package for increased liveweight gains and milk production in Red Sokoto goats.

(c) 2003 Elsevier B.V. All rights reserved.
\end{abstract}

Keywords: Red Sokoto goats; Crop residue; Supplementation; Weight gains; Milk yield; Milk composition

\footnotetext{
*Corresponding author. Present address: Laboratory of Animal Breeding and Reproduction, National Agricultural Research Centre for Western Region, 60 Yoshinaga, Kawai, Oda, Shimane 694-0013, Japan. Tel.: +81-854-82-1285; fax: +81-854-82-2280.

E-mail address: aduli40@yahoo.co.uk (A.E.O. Malau-Aduli).
}

\section{Introduction}

Between 40 and $100 \%$ of patients allergic to cow milk tolerate goat milk (Park, 1994). Goat milk has 
been recommended as a substitute for those who suffer from allergies to cow milk or other food sources (Van der Horst, 1976). Therefore, there is a growing awareness of the importance of goats as a source of milk for man (Prakash and Jenness, 1968) and worldwide, more people drink goat milk than milk from other species (Park and Chukwu, 1989). The potential for increased use of goats as the most effective animals for milk production in many developing countries is quite high. The Northern regions of Nigeria have most of the nation's ruminant livestock. However, these areas are characterised by a long and pronounced dry season (6-9 months), and this often causes serious shortage of feed for the ruminants. The problem of dry season livestock feeding in particular, has directed research efforts towards harnessing and enhancing the utilization of arable byproducts and crop residues. The abundance of crop residues makes them cheap sources of nutrients for ruminants. Nevertheless, they are generally low in nutrients (Nicholson, 1984). Various strategies have been adopted to improve their nutrients and utilisation (Leng, 1990). One such is judicious supplementation to provide the most limiting nutrients (Preston, 1982; Alhassan, 1988). However, appropriate feeding packages for improved liveweight gains and milk production to guide small ruminant producers in Nigeria have not been developed. Also, relevant information on cheap, alternative sources of feeds crucial to dry season feeding in Nigeria's subhumid zone has not been passed on to small ruminant producers. Therefore, this study was undertaken to determine the nutrient composition, intakes, digestibilities and affordability of some locally available crop residue feed resources and their impact on liveweight gain, milk yield and composition of Red Sokoto goats in the subhumid zone of Nigeria, in comparison with the conventional concentrate supplementation ration.

\section{Materials and methods}

\subsection{Location and management of experimental animals}

The experiments were conducted during the dry seasons (between October and March) in the Experimental Unit of the Small Ruminant Research
Programme of the National Animal Production Research Institute, Shika, Zaria, Nigeria. Shika falls between latitudes 11 and $12^{\circ} \mathrm{N}$ and between longitudes 7 and $8^{\circ} \mathrm{E}$, with an altitude of $640 \mathrm{~m}$ above sea level. Shika is located within the Northern Guinea Savannah Zone with an average annual rainfall and temperature of $1107 \mathrm{~mm}$ and $24.4^{\circ} \mathrm{C}$, respectively. The seasonal distribution of the annual rainfall is approximately $0.1 \%(11.0 \mathrm{~mm})$ in the late dry season (January-March), 25.8\% (285.6 mm) in the early wet season (April-June), 69.6\% (770.4 $\mathrm{mm})$ in the late wet season (July-September) and $4.5 \%(49.8 \mathrm{~mm})$ in the early dry season (OctoberDecember). The animals were routinely dewormed with anthelmintic drugs and dipped in an acaricide (Asuntol) solution against ectoparasites. The animals were housed in well-ventilated pens during the night.

\subsection{Digestibility trial}

Twenty-eight adult Red Sokoto does ranging between 24.6 and $26.4 \mathrm{~kg}$ were used for this experiment. The animals were balanced for weight and blocked into seven groups with four animals per group. The component ingredients in the different rations are shown in Table 1. Each doe was individually offered its appropriate corresponding ration to evaluate the digestibility of the diets. The study comprised a 2-week preliminary period of realimentation and adjustment, and 1 week of sample collection. The animals were housed in individual metabolism cages with facilities for separate collection of faeces and urine. The animals were weighed at the beginning and end of the study. Faeces were collected each morning just before feeding. A sample of $10 \%$ of each daily faecal output was collected for chemical analyses. Samples of the different rations fed were taken daily and bulked, from which subsamples were taken for laboratory analysis. Also, samples of the individual feed ingredients were analysed in the laboratory. Water was made available to the animals ad libitum. The inventory, abundance and palatability of the plant species in the grazed paddock was conducted as described by Lakpini et al. (1997).

\subsection{Milk yield and composition}

Measurements for milk yield and composition 
Table 1

Component ingredients in the different rations

\begin{tabular}{|c|c|c|c|}
\hline Ration & Ingredients & Inclusion (\%) & Remarks \\
\hline $1 \mathrm{~A}+$ Basal diet & $\begin{array}{l}\text { Maize } \\
\text { Wheat offal } \\
\text { Cottonseed cake } \\
\text { Bone meal } \\
\text { Salt }\end{array}$ & $\begin{array}{r}40 \\
35 \\
20 \\
3 \\
2\end{array}$ & $\begin{array}{l}\text { Positive control } \\
\text { (conventional concentrate) } \\
\text { offered at } 1 \% \text { of } \\
\text { body weight }\end{array}$ \\
\hline $2 \mathrm{~A}+$ Basal diet & $\checkmark$ & $\checkmark$ & $\begin{array}{l}\text { Positive control } \\
\text { (conventional concentrate) } \\
\text { offered at } 2 \% \text { of } \\
\text { body weight }\end{array}$ \\
\hline 1B + Basal diet & $\begin{array}{l}\text { Guinea-corn bran } \\
\text { Cowpea husk } \\
\text { G/Nut haulms } \\
\text { Salt }\end{array}$ & $\begin{array}{l}39.5 \\
30 \\
30 \\
0.5\end{array}$ & $\begin{array}{l}\text { Test Ration } 1 \text { offered } \\
\text { at } 1 \% \text { of body weight }\end{array}$ \\
\hline $2 \mathrm{~B}+$ Basal diet & $\checkmark$ & $\checkmark$ & $\begin{array}{l}\text { Test Ration } 1 \text { offered } \\
\text { at } 2 \% \text { of body weight }\end{array}$ \\
\hline $1 \mathrm{C}+$ Basal diet & $\begin{array}{l}\text { Maize offal } \\
\text { G/Nut shells } \\
\text { G/Nut haulms } \\
\text { Salt }\end{array}$ & $\begin{array}{l}49.5 \\
20 \\
30 \\
0.5\end{array}$ & $\begin{array}{l}\text { Test Ration } 2 \text { offered } \\
\text { at } 1 \% \text { of body weight }\end{array}$ \\
\hline $2 \mathrm{C}+$ Basal diet & $\checkmark$ & $\checkmark$ & $\begin{array}{l}\text { Test Ration } 2 \text { offered } \\
\text { at } 2 \% \text { of body weight }\end{array}$ \\
\hline $\begin{array}{l}\text { D } \\
\text { (Basal diet) }\end{array}$ & $\begin{array}{l}\text { Digitaria hay and } \\
\text { dry season naturally } \\
\text { grazed pasture }\end{array}$ & Ad libitum & $\begin{array}{l}\text { Negative control } \\
\text { (unsupplemented) }\end{array}$ \\
\hline
\end{tabular}

commenced from day 7 postpartum to allow kids access to all their dams' colostrum. Thereafter, the kids were separated from their dams and moved to the bucket-fed unit. The two halves of the udder of each lactating doe were hand-milked early in the morning and in the evenings. The quantity of milk collected at each milking was recorded and does were monitored from a week after delivery to the last day of milk let-down when the total lactation length was recorded. Daily milk yield was bulked from weeks 2 to 6 for laboratory analysis to determine milk composition using AOAC (1980) procedures.

\subsection{Laboratory analyses}

Proximate analyses of feed and faecal samples were carried out by the AOAC (1980) methods. Dry matter of samples was determined by drying the samples in an oven at $105^{\circ} \mathrm{C}$ for $48 \mathrm{~h}$. Nitrogen determination was by the micro-Kjedahl method, while the Soxhlet extraction procedure was used for ether extraction. Crude fibre was determined by alternate refluxing with weak solutions of $\mathrm{H}_{2} \mathrm{SO}_{4}$ and $\mathrm{KOH}$. The detergent fibre fractions (neutral detergent fibre, acid detergent fibre and lignin) were determined according to Goering and Van Soest (1970). Dry matter intake (DMI) was determined using the following equation:

$\mathrm{DMI}(\mathrm{g} /$ day $)=\% \mathrm{DM} / 100 \times$ feed intake

Dry matter digestibility (DMD (\%)) was calculated as:

[DM intake $(\mathrm{g})-$ DM output $(\mathrm{g}) / \mathrm{DM}$ intake $(\mathrm{g})] \times$ 100

The other digestibilities were calculated as above.

\subsection{Statistical analysis}

Differences in feed intake, digestibility, liveweight gain, milk yield and composition were analysed using the generalised linear models procedure (PROC GLM) of SAS (1987). The effect of treatment was 
tested and significant differences between treatment means established by Duncan's multiple range test.

\section{Results}

The chemical composition of the individual feed ingredients and the experimental diets are shown in Tables 2 and 3, respectively. Table 3 shows that all the rations had high dry matter (DM) contents with a mean value of about $95 \%$. Ration A had the highest crude protein $(\mathrm{CP})$ followed by Rations $\mathrm{B}$ and $\mathrm{C}$. The $\mathrm{CP}$ value of the dry season grazed pastures was the lowest. The least ash content value was obtained in Ration D: hay $(8.47 \%)$ and grazed pasture $(7.02 \%)$. The highest ash content was obtained in Ration A. Ration A also had the highest ether extract (EE) and Ration D, the least. Acid detergent fibre (ADF), neutral detergent fibre (NDF) and lignin contents were least in Ration A. Ration D on the other hand, contained the highest ADF, NDF and lignin values. The calculated chemical analysis of the experimental rations (Table 3) revealed that Ration A had a CP content of $17.05 \%$ while the test rations $\mathrm{B}$ and $\mathrm{C}$ had 9.82 and $10.85 \%$, respectively. Ration A also had a metabolisable energy (ME) of 11.17 $\mathrm{MJ} / \mathrm{kg}$ DM, while Rations B and C had 10.29 and $10.17 \mathrm{MJ} / \mathrm{kg} \mathrm{DM}$, respectively. Table 4 shows the $\mathrm{DM}$ and $\mathrm{CP}$ intakes and digestibilities of the nutrients. The table shows that generally, the supplemented groups had significantly higher $(P<0.05)$ $\mathrm{DM}$ and $\mathrm{CP}$ intakes and digestibilities than the unsupplemented group except animals on Ration B that had similar values to the unsupplemented group. It was also evident that increasing the level of supplementation also resulted in significantly $(P<$ 0.05 ) increased $\mathrm{DM}$ and $\mathrm{CP}$ intakes. It was also observed that supplementation increased the digestibility of all the nutrients. However, animals on Ration B recorded very poor digestibility values and

Table 2

Chemical composition of the major feed ingredients (DM basis) (\%)

\begin{tabular}{|c|c|c|c|c|c|c|}
\hline Feedstuff & $\mathrm{DM}$ & $\mathrm{CP}$ & $\mathrm{CF}$ & Ash & $\mathrm{EE}$ & NFE \\
\hline Maize & 90.73 & 9.56 & 2.20 & 9.67 & 4.05 & 74.52 \\
\hline Wheat offal & 87.60 & 16.90 & 11.30 & 6.40 & 3.80 & 61.60 \\
\hline Cottonseed cake & 93.60 & 29.94 & 23.50 & 5.16 & 5.76 & 35.64 \\
\hline Bone meal & 75.00 & 36.00 & 3.00 & 49.00 & 4.00 & 8.00 \\
\hline Guinea corn bran & 93.33 & 7.60 & 24.80 & 6.95 & 3.01 & 59.90 \\
\hline Cowpea husks & 91.41 & 7.10 & 33.40 & 7.14 & 0.65 & 58.91 \\
\hline Groundnut haulms & 93.65 & 15.63 & 23.26 & 8.0 & 2.43 & 51.0 \\
\hline Maize offal & 89.07 & 10.08 & 1.5 & 0.8 & 1.7 & 60.30 \\
\hline Groundnut shells & 96.05 & 5.90 & 31.8 & 8.5 & 1.31 & 50.3 \\
\hline
\end{tabular}

Table 3

Chemical composition of the experimental diets (dry matter basis) $(\%)$

\begin{tabular}{|c|c|c|c|c|c|c|c|}
\hline Ration & $\mathrm{DM}$ & $\mathrm{CP}$ & Ash & $\mathrm{EE}$ & $\mathrm{ADF}$ & $\mathrm{NDF}$ & LIGNIN \\
\hline Ration A & 93.87 & 17.19 & 13.85 & 14.08 & 20.00 & 40.01 & 4.64 \\
\hline Ration B & 94.97 & 9.54 & 10.55 & 10.43 & 38.10 & 68.42 & 8.94 \\
\hline Ration C & 95.94 & 10.38 & 11.97 & 12.45 & 36.65 & 54.74 & 8.23 \\
\hline Ration D (Hay) & 94.78 & 4.75 & 8.47 & 2.40 & 49.14 & 74.73 & 9.49 \\
\hline $\begin{array}{l}\text { Ration D (dry season } \\
\text { naturally grazed pastures) }\end{array}$ & 96.26 & 2.76 & 7.02 & 0.78 & 50.29 & 80.27 & 11.5 \\
\hline \multicolumn{8}{|c|}{ Calculated analysis of the experimental rations } \\
\hline & Ration A & Ration B & Ration C & & & & \\
\hline $\mathrm{CP}(\%)$ & 17.05 & 9.82 & 10.85 & & & & \\
\hline $\mathrm{ME}(\mathrm{MJ} / \mathrm{kg} \mathrm{DM})$ & 11.17 & 10.29 & 10.17 & & & & \\
\hline
\end{tabular}

The ME values of the experimental rations were calculated as per Alderman (1985): $\mathrm{ME}(\mathrm{MJ} / \mathrm{kg} \mathrm{DM})=11.78+0.00654 \mathrm{CP}+$ $(0.000665 \mathrm{EE})^{2}-\mathrm{CF}(0.00414 \mathrm{EE})-0.0118 \mathrm{~A}$ where $\mathrm{CP}=$ crude protein, $\mathrm{EE}=$ ether extract, $\mathrm{CF}=$ crude fibre, $\mathrm{A}=\mathrm{ash}$. 
Table 4

Mean nutrient intake, apparent digestibility coefficients and cost of the experimental diets

\begin{tabular}{|c|c|c|c|c|c|c|c|c|}
\hline Ration & $1 \mathrm{~A}$ & $2 \mathrm{~A}$ & $1 \mathrm{~B}$ & $2 \mathrm{~B}$ & $1 \mathrm{C}$ & $2 \mathrm{C}$ & $\mathrm{D}$ & S.E.M. \\
\hline \multicolumn{9}{|c|}{ Nutrient intake $(\mathrm{kg} /$ day $)$} \\
\hline DMI & $0.24^{\mathrm{b}}$ & $0.47^{\mathrm{a}}$ & $0.21^{\mathrm{bc}}$ & $0.30^{\mathrm{ab}}$ & $0.23^{\mathrm{b}}$ & $0.42^{\mathrm{a}}$ & $0.15^{\mathrm{c}}$ & \pm 0.02 \\
\hline CPI & $0.044^{\mathrm{a}}$ & $0.087^{\mathrm{a}}$ & $0.012^{\mathrm{b}}$ & $0.017^{\mathrm{b}}$ & $0.032^{\mathrm{a}}$ & $0.072^{\mathrm{a}}$ & $0.009^{\mathrm{b}}$ & \pm 0.01 \\
\hline \multicolumn{9}{|c|}{ Apparent digestibility of nutrients (\%) } \\
\hline $\mathrm{DM}$ & $84.3^{\mathrm{a}}$ & $83.0^{\mathrm{a}}$ & $62.5^{\mathrm{d}}$ & $60.5^{\mathrm{e}}$ & $75.8^{\mathrm{b}}$ & $67.8^{\mathrm{c}}$ & $56.4^{\mathrm{f}}$ & \pm 2.84 \\
\hline $\mathrm{CP}$ & $90.6^{\mathrm{a}}$ & $89.2^{\mathrm{a}}$ & $69.5^{\mathrm{d}}$ & $65.5^{\mathrm{e}}$ & $82.7^{\mathrm{b}}$ & $78.1^{\mathrm{c}}$ & $48.4^{\mathrm{f}}$ & \pm 3.07 \\
\hline NDF & $69.5^{\mathrm{a}}$ & $66.6^{\mathrm{b}}$ & $62.1 \mathrm{c}^{\mathrm{d}}$ & $61.9^{d}$ & $65.9^{\mathrm{b}}$ & $63.7^{\mathrm{c}}$ & $60.1^{\mathrm{e}}$ & \pm 3.23 \\
\hline $\mathrm{ADF}$ & $51.7^{\mathrm{a}}$ & $49.8^{\mathrm{a}}$ & $43.9^{\mathrm{bc}}$ & $42.8^{\mathrm{c}}$ & $46.1^{\mathrm{b}}$ & $44.4^{\mathrm{bc}}$ & $42.3^{\mathrm{bc}}$ & \pm 5.01 \\
\hline \multicolumn{9}{|c|}{ Economic analysis of the feeds (Naira)* } \\
\hline $\begin{array}{l}\text { Cost of feed } \\
\text { consumed per } \\
\text { animal per day }\end{array}$ & $2.19^{\mathrm{b}}$ & $4.42^{\mathrm{a}}$ & $0.50^{\mathrm{e}}$ & $1.06^{\mathrm{d}}$ & $0.83^{\mathrm{de}}$ & $1.55^{\mathrm{c}}$ & - & \pm 0.15 \\
\hline
\end{tabular}

a,b,c,d,e,f, Means within the same row bearing different superscript letters differ significantly $(P<0.05)$.

*, Naira $=$ Nigerian currency (100 kobo make 1 Naira and current exchange rate is 1 US $\$=140$ Naira).

their counterparts in the unsupplemented group had the least. Even though the digestibility of nutrients decreased with increasing levels of supplementation, these decreases were not significant $(P>0.05)$. Ration $1 \mathrm{~A}$ (the conventional concentrate at $1 \%$ of body weight) gave the highest digestibility values. A comparison of the unsupplemented animals with all the other treatment groups reveals that DM digestibility improved by a range of $4.1-27.9 \%$ and $\mathrm{CP}$ digestibility by $17.1-42.2 \%$, the highest being in animals on Ration A at $1 \%$ level. Similar improvements trends were also noticeable for neutral detergent fibre (NDF) and acid detergent fibre (ADF). A simple economic analysis (Table 4) revealed that the conventional concentrate feed was the most expensive for supplementation particularly, at the $2 \%$ level (4.42 naira per animal per day). Of the two tested crop-residue rations, Ration 1B was significantly cheaper $(P<0.05)$ than Rations $2 \mathrm{~B}$ and $2 \mathrm{C}$, but similar to Ration 1C.

The effect of ration supplementation on weight gains and average daily gains of the dams are depicted in Table 5. It shows that by the end of the study, dams fed rations $1 \mathrm{~B}$ and D lost weights (2.0 and $6.5 \mathrm{~kg}$, mean loss of 28.57 and $92.86 \mathrm{~g} /$ day, respectively), while those on ration $2 \mathrm{C}$ gained the highest weight of $2.75 \mathrm{~kg}$, mean gain of $39.29 \mathrm{~g} /$ day. This was followed by rations $2 \mathrm{~A}$ and $1 \mathrm{C}$ with $1.5 \mathrm{~kg}$ weight gain each, mean gain of $21.43 \mathrm{~g} /$ day.

Table 6 shows results of the lactation length, total milk yield and average daily milk yield of does on different rations. Dams on Rations $1 \mathrm{~A}$ and $2 \mathrm{~A}$ lactated for 80 and 88 days, gave total milk yields of 38.4 and $54.5 \mathrm{~kg}$ and averaging 0.48 and $0.62 \mathrm{~kg} /$

Table 5

Effect of ration supplementation on weight gain in Red Sokoto does ( \pm S.E.M.)

\begin{tabular}{lcccr}
\hline Ration & $\begin{array}{l}\text { Initial wt. } \\
(\mathrm{kg})\end{array}$ & $\begin{array}{l}\text { Final wt. } \\
(\mathrm{kg})\end{array}$ & \multicolumn{1}{c}{$\begin{array}{l}\text { Wt. gain } \\
(\mathrm{kg})\end{array}$} & $\begin{array}{l}\text { ADG } \\
(\mathrm{g} / \mathrm{day})\end{array}$ \\
\hline 1A & 29.00 & $29.25^{\mathrm{a}}$ & $0.25^{\mathrm{d}}$ & $3.57^{\mathrm{d}}$ \\
2A & 27.50 & $29.00^{\mathrm{a}}$ & $-50^{\mathrm{b}}$ & $21.43^{\mathrm{b}}$ \\
1B & 29.75 & $27.75^{\mathrm{b}}$ & $-2.00^{\mathrm{e}}$ & $1.00^{\mathrm{c}}$ \\
2B & 28.75 & $29.75^{\mathrm{a}}$ & $1.50^{\mathrm{b}}$ & $28.57^{\mathrm{e}}$ \\
1C & 27.25 & $28.75^{\mathrm{b}}$ & $2.75^{\mathrm{a}}$ & $21.43^{\mathrm{b}}$ \\
2C & 26.75 & $29.50^{\mathrm{a}}$ & $-6.5^{\mathrm{f}}$ & $39.29^{\mathrm{a}}$ \\
D & 27.25 & $20.75^{\mathrm{c}}$ & \pm 0.12 & $-92.86^{\mathrm{f}}$ \\
土S.E.M & \pm 4.25 & \pm 4.30 & \pm 1.82 \\
\hline
\end{tabular}

Column means bearing different superscripts differ from each other significantly $(P<0.01)$. 
Table 6

Effect of ration supplementation on lactation length, total milk yield and average daily milk yield ( \pm S.E.M.) in Red Sokoto does

\begin{tabular}{llll}
\hline Ration & $\begin{array}{l}\text { Lactation } \\
\text { length } \\
(\text { days })\end{array}$ & $\begin{array}{l}\text { Total milk } \\
\text { yield } \\
(\mathrm{kg})\end{array}$ & $\begin{array}{l}\text { Average } \\
\text { daily yield } \\
(\mathrm{kg})\end{array}$ \\
\hline 1A & $80^{\mathrm{a}}$ & $38.4^{\mathrm{b}}$ & $0.48^{\mathrm{b}}$ \\
2A & $88^{\mathrm{a}}$ & $54.5^{\mathrm{a}}$ & $0.62^{\mathrm{a}}$ \\
1B & $48^{\mathrm{c}}$ & $12.9^{\mathrm{d}}$ & $0.27^{\mathrm{d}}$ \\
2B & $64^{\mathrm{b}}$ & $23.0^{\mathrm{c}}$ & $0.36^{\mathrm{c}}$ \\
1C & $90^{\mathrm{a}}$ & $54.0^{\mathrm{a}}$ & $0.60^{\mathrm{a}}$ \\
2C & $72^{\mathrm{b}}$ & $35.5^{\mathrm{b}}$ & $0.45^{\mathrm{b}}$ \\
D & $41^{\mathrm{c}}$ & $10.2^{\mathrm{d}}$ & $0.25^{\mathrm{d}}$ \\
S.E.M. & \pm 4.7 & \pm 3.3 & \pm 0.03 \\
\hline
\end{tabular}

Column means bearing different superscripts differ from each other significantly $(P<0.01)$.

day, respectively. Interestingly, Ration 1C which comprised of mainly crop residue with much lesser protein levels produced $54 \mathrm{~kg}$ of milk over a 90-day lactation averaging $0.60 \mathrm{~kg}$ per day. At the other extreme, dams that fed on the negative control ration D comprising of Digitaria hay and natural grazed pastures, had the shortest lactation length and therefore least total and average daily milk yields (Table $6)$.

Results of the milk composition of Red Sokoto does is shown in Table 7. It was evident that in absolute terms, milk from does on Ration $2 \mathrm{~A}$ contained the highest percentages of fat, protein, total solids and SNF. As expected, milk from does on the negative control ration ranked least with respect to all the parameters studied. Phenotypic correlations between the milk components (total solids, crude protein, fat and solids-not-fat) were positive, and the highest correlation of 0.84 was between total solids and crude protein (excluding the perfect correlation of 1.00 between a variable and itself). This indicates a very strong relationship between these components in which there is a corresponding increase in crude protein as total solids percentage increases and vice versa. However, between solids-not-fat and fat, though positive, was not significant $(0.38)$.

\section{Discussion}

The quantity and type of ingredients used in formulating the rations influenced their chemical compositions. In Ration A, the inclusion of wheat offal and cottonseed cake boosted the protein level of the ration giving it a value of $17.19 \%$. This value is higher than the recommended CP level of $15 \%$ for optimum maintenance of production by Nuru (1985) and $8.9-16.0 \%$ by NRC (1975). The metabolisable energy (ME) value of Ration A (11.17 MJ $/ \mathrm{kg} \mathrm{DM})$ is also higher than the $9.5 \mathrm{MJ} / \mathrm{kg} \mathrm{DM}$ recommended for maintenance by INRA (1988), but lower than the latter's recommended value for pregnant and lactating goats. Rations $\mathrm{B}$ and $\mathrm{C}$ had similar $\mathrm{CP}$ and $\mathrm{ME}$ values indicating that they are isocaloric and isonitrogenous rations. The preponderance of crop residues in Rations B and C was responsible for their high crude fibre and lignin levels. The current study showed that, in spite of Rations $\mathrm{B}$ and $\mathrm{C}$ being isocaloric and isonitrogenous, animals on Ration $\mathrm{C}$ had better intakes and digestibilities than those on Ration B, possibly due to the low palatability, hence low voluntary intake, and poor digestibility of Ration B.

The observed higher digestibilities of DM, CP,

Table 7

Effect of ration supplementation on milk composition of Red Sokoto does ( \pm S.E.M)

\begin{tabular}{lccccc}
\hline Ration & Fat & Protein & SNF & Total solids & Ash \\
\hline $1 \mathrm{~A}$ & $5.66^{\mathrm{a}}$ & $6.00^{\mathrm{a}}$ & $15.75^{\mathrm{a}}$ & $21.41^{\mathrm{a}}$ & 0.81 \\
2A & $6.00^{\mathrm{a}}$ & $6.33^{\mathrm{a}}$ & $15.85^{\mathrm{a}}$ & $21.85^{\mathrm{a}}$ & 0.83 \\
1B & $3.50^{\mathrm{d}}$ & $3.67^{\mathrm{b}}$ & $10.75^{\mathrm{c}}$ & $14.25^{\mathrm{c}}$ & 0.76 \\
2B & $3.75^{\mathrm{d}}$ & $4.90^{\mathrm{b}}$ & $13.75^{\mathrm{b}}$ & $17.50^{\mathrm{b}}$ & 0.79 \\
1C & $4.33^{\mathrm{c}}$ & $6.00^{\mathrm{a}}$ & $15.66^{\mathrm{a}}$ & $19.99^{\mathrm{a}}$ & 0.80 \\
2C & $5.25^{\mathrm{b}}$ & $6.67^{\mathrm{a}}$ & $16.00^{\mathrm{a}}$ & $21.25^{\mathrm{a}}$ & 0.82 \\
D & $2.33^{\mathrm{e}}$ & $3.25^{\mathrm{c}}$ & $10.00^{\mathrm{c}}$ & $12.33^{\mathrm{c}}$ & \pm .75 \\
\pm S.E.M. & \pm 0.7 & \pm 0.8 & \pm 1.3 & \pm 1.8 & \pm 0.05 \\
\hline
\end{tabular}

Column means bearing different superscripts are significantly different $(P<0.05)$. 
$\mathrm{NDF}$ and $\mathrm{ADF}$ at $1 \%$ level (rations $1 \mathrm{~A}, 1 \mathrm{~B}, 1 \mathrm{C}$ ) in comparison to $2 \%$ level (rations 2A, 2B, 2C) can be attributed to the higher feed intake at the $2 \%$ level of inclusion. It has been established that higher feed intake results in a faster rate of passage of digesta from the reticulo-rumen (Swan and Lamming, 1967). This does not allow for effective degradation, hence lowering the digestibility of the feed. Increasing the level of crop residue in the diet also increased the amount of lignin, which depressed the digestibility of the ration (McDonald et al., 1988), because the rate of microbial colonisation of a feed with high fibre content is comparatively lower (Silva and Orskov, 1988). The poor intake and digestibility values obtained for the unsupplemented animals is due to the fact that Ration D had crude protein levels that are below the recommended minimum values for maintenance. This shows that there is the need for dry season supplementation in goats because the available feeds at that time are limiting in crude protein.

Of the two tested rations, Ration $\mathrm{C}$ seemed to have produced better intakes and digestibilities in the animals, possibly due to the composition of the rations. It contained maize offal which has very low fibre content (Alawa and Umunna, 1993), groundnut haulms which have been demonstrated to be better quality roughages than Digitaria smutsii hay and contain adequate protein to maintain ruminants without any form of supplementation during the periods of feed scarcity (Ikhatua and Adu, 1984). The groundnut shells fed to the animals were also crushed before inclusion into the ration as suggested by Alawa and Umunna (1993). This must have aided their consumption and digestibility. Even though Ration B contained groundnut haulms, the combination of Guinea corn bran and cowpea husk which had low crude protein percentages, must have reduced the intake and digestibility of the ration. Alhassan et al. (1984) observed lower digestibility values in sheep and goats (48.8 and 56.3\%, respectively) compared with cattle $(73.6 \%)$ when they fed them cowpea vines. This might imply that cattle do better on cowpea residues than small ruminants. From the economic analysis, the high cost of the conventional concentrate ration shows that it is beyond the reach of a typical smallholder goat farmer, whereas the crop-residue-based rations seem quite affordable.
Even though Ration B had the least cost, it was obvious that it had lower intake and digestibility compared to Ration $\mathrm{C}$, indicating in essence, that Ration $\mathrm{C}$ had a better efficiency of utilisation.

The effects of various crop residues on feed intake, liveweight gains and growth performance of ruminants have been reported by Adu and Lakpini (1983b) and Ikhatua and Adu (1984). Adu and Lakpini (1983b) obtained liveweight gains of $90.2 \mathrm{~g}$ per day in Yankasa lambs fed sole diet of unchopped groundnut haulms. In the study by Ikhatua and Adu (1984), supplementation of groundnut haulms with concentrate further enhanced intake and performance of the animals. Similar effects of supplementation have been observed in this study.

The efficiency of conversion of feed to meat as reflected by liveweight gains, was highest in does fed ration $2 \mathrm{C}$ and lowest in those fed rations $\mathrm{D}$ and $1 \mathrm{~B}$. The better weight gains of does fed ration $2 \mathrm{C}$ over those fed the conventional concentrate ration (1A and $2 \mathrm{~A}$ ) indicate that does in the latter groups converted more of their feed to milk rather than meat as evidenced by their higher milk yield values. The observed liveweight gains in this study were lower than those reported by Adeneye and Oyenuga (1976), Adu and Lakpini (1983a,b) and Ikhatua and Adu (1984). However, they agreed with the report of Adebowale (1989) who included 40\% untreated maize cobs in the diets of goats and obtained 24.9 $\mathrm{g} /$ day weight gain. The weight losses observed in does fed rations $1 \mathrm{~B}$ and $\mathrm{D}$ could be attributed to the low palatability, low intake and poor digestibility of the feeds.

The milk yield, lactation length and milk composition values in the present study were in agreement with those of other experiments with goats reported by Prakash and Jenness (1968), Ramos and Juarez (1981) and Sibanda et al. (1999). This study also confirmed that the milk yield of goats could be improved by supplementing their pasture diets with some concentrates (Garmo, 1986; Ahmed et al., 2001). The observed values of total milk yield, lactation length and average daily yield in goats fed rations $2 \mathrm{~A}$ and $1 \mathrm{C}$ were higher than those reported by Adu et al. (1979), Akinsoyinu et al. (1982) and Ehoche and Buvanendran (1983). This increase in milk yield may be due to improvement as a result of selection over the years within the Red Sokoto breed. 
The inference that can be drawn from this observation is that feeding lactating does on ration $1 \mathrm{C}$ irrespective of the fact that it was a mainly crop residue ration, gave just as good a result in terms of average daily and total milk yields, as full concentrate rations. This holds hope for smallholders interested in improving the milk yield of their Red Sokoto dams without necessarily embarking on an expensive concentrate ration. It was observed that although the animals on rations $\mathrm{B}$ and $\mathrm{D}$ had diets with high crude fibre (CF), ADF and NDF, the fat levels of their milk compositions were the least. This did not conform to the reports by Sachdeva et al. (1974) and Abdel-Rahman and Mehaia (1996), possibly because the diets in this study were not as palatable as the other diets and therefore were not consumed well enough.

The significantly strong and positive correlations $(P<0.001)$ between the percentages of milk crude protein, total solids, fat and solids-not-fat obtained in this study agreed with the findings of Mba et al. (1975), Akinsoyinu et al. (1982), Ehoche and Buvanendran (1983) (for fat and protein), Fajemisin and Mohammed (1990) (unpublished paper) and Malau-Aduli and Anlade (2001, 2002). The observed highly positive correlations between the milk components will aid genetic improvement by incorporating these traits in a selection index.

In conclusion, goats are able to subsist and make appreciable gains even in the long dry seasons of the subhumid zone of Nigeria on crop-residue-based diets. This study has also demonstrated that ration $\mathrm{C}$ elicited as much favourable response in the liveweight gain, milk yield and composition of Red Sokoto goats as the conventional concentrate ration A, which may be too expensive for the local farmer to purchase. Furthermore, Ration $\mathrm{C}$ was a better package than Ration $\mathrm{B}$ and is therefore recommended at $1 \%$ level of inclusion, to small ruminant farmers due to its high intake and digestibility as well as its affordability than at $2 \%$ level of inclusion.

\section{Acknowledgements}

The authors gratefully acknowledge the support of the International Atomic Energy Agency (IAEA) Vienna, Austria, in partly funding this project through the supply of chemicals, and to the Director of the National Animal Production Research Institute, Ahmadu Bello University Shika-Zaria for permission to publish this work.

\section{References}

Abdel-Rahman, J., Mehaia, M., 1996. Influence of feeding different crude fibre levels on milk yield and composition of Najdi ewes. Small Rum. Res. 19, 137-141.

Adebowale, E.A., 1989. Response of West African Dwarf sheep and goats fed maize cobs treated with different concentrations of caustic soda. Trop. Agric. (Trinidad) 66, 213-216.

Adeneye, J.A., Oyenuga, V.A., 1976. Energy and protein requirements of West African Dwarf sheep: 1. Effects of feeding four levels of dietary energy to sheep. E. Afr. Agric. J. 42, 89-97.

Adu, I.F., Buvanendran, V., Lakpini, C.A.M., 1979. The reproductive performance of Red Sokoto goats in Nigeria. J. Agric. Sci. (Cambridge) 93, 563-566.

Adu, I.F., Lakpini, C.A.M., 1983a. The utilisation of dried poultry as protein supplement for growing Yankasa sheep. J. Anim. Prod. Res. 3, 49-56.

Adu, I.F., Lakpini, C.A.M., 1983b. Effect of feeding chopped and unchopped groundnut haulms (Harawa) on nutrient utilisation and the production of rumen metabolites in Yankasa lambs. Nigerian J. Anim. Prod. 10, 110-113.

Ahmed, M.M.M., El Hag, F.M., Wahab, F.S., Salih, S.F., 2001. Feeding strategies during summer for lactating desert goats in a rain-fed area under tropical conditions. Small Rum. Res. 39, $161-166$.

Akinsoyinu, A.O., Tewe, O.O., Ngere, L.O., Mba, A.U., 1982. Milk composition and yield of the Red Sokoto (Maradi) goats. Dairy Sci. Abstr. 43, 83-84.

Alawa, J.P., Umunna, N.N., 1993. Alternative feed formulation in the developing countries: Prospects for utilisation of agroindustrial byproducts. J. Anim. Prod Res. 13, 63-98.

Alderman, G., 1985. Prediction of the energy value of compound feeds. In: Haresign, W., Cole, D.J.A. (Eds.), Recent Advances in Animal Nutrition. Butterworths, London.

Alhassan, W.S., Ehoche, O.W., Adu, I.F., Obilara, T.A., Kallah, M.S., 1984. Crop residue potential of agricultural development projects: nutritive value and residue management. In: NAPRI Annual Report. National Animal Production Research Institute, Shika, pp. 35-45.

Alhassan, W.S., 1988. Crop residue utilisation with special reference to pastoral production: Past, present and future. Proceedings, National Conference on Pastoralism in Nigeria, 26-27th June, 1988, pp. 70-87.

AOAC, 1980. Official Methods of Analysis, 13th Edition. Association of Official Analytical Chemists, Washington, DC.

Ehoche, O.W., Buvanendran, V., 1983. The yield and composition of milk and preweaning growth rate of Red Sokoto goats in Nigeria. World Rev. Anim. Prod. 19, 19-24.

Garmo, T.H., 1986. Dairy goat grazing on mountain pasture. I. 
Effect of supplementary feeding. Neld. No. 2. Landbzukshwegsk 241, 1-19.

Goering, H.K., Van Soest, P.J., 1970. Forage fibre analysis (apparatus, reagents, procedures and some applications). Agricultural Handbook 379, ARS, USDA, Washington, DC.

Ikhatua, U.I., Adu, I.F., 1984. A comparative evaluation of the utilization of groundnut haulms and Digitaria hay by Red Sokoto goats. J. Anim. Prod. Res. 4, 145-152.

INRA, 1988. Alimentation des Bovins, Ovins et Caprins. Institut National de la Recherché Agronomique, Paris.

Lakpini, C.A.M., Balogun, B.I., Alawa, J.P., Onifade, O.S., Otaru, S.M., 1997. Effects of graded levels sun-dried cassava peels in supplement diets fed to Red Sokoto goats in the first trimester of pregnancy. Anim. Feed Sci. Technol. 67, 197-204.

Leng, R.A., 1990. Factors affecting the utilisation of poor quality forages by ruminants particularly under tropical conditions. Nutrit. Res. Rev. 3, 277-303.

Malau-Aduli, A.E.O., Anlade, Y.R., 2001. Variations and correlations in the composition of bovine, ovine and caprine milk. Proc. Nigerian Soc. Anim. Prod. 26, 7-9.

Malau-Aduli, A.E.O., Anlade, Y.R., 2002. Comparative study of milk compositions of cattle, sheep and goats in Nigeria. Animal Sci. J. 73, 541-544.

Mba, A.U., Boyo, B.S., Oyenuga, V.A., 1975. Studies on the milk composition of West African Dwarf. Red Sokoto and Saanen goats at different stages of lactation. J. Dairy Res. 42, 217226.

McDonald, P., Edwards, R.A., Greenhalgh, J.F.D., 1988. Animal Nutrition, 4th Edition. Longman Scientific and Technical, UK.

Nicholson, J.W.G., 1984. Digestibility, nutritive values and intake. In: Sundstol, F., Owen, E. (Eds.), Straw and Other Fibrous Feeds. Elsevier, Amsterdam, Chapter 12.

NRC, 1975. Nutrient requirements of sheep. In: Nutrient Requirements of Domestic Animals, 5th Edition. National Research Council, Washington, DC.
Nuru, S., 1985. Strategies for Improved Production of Fresh Foods in Nigeria. Nigerian Institute of Food Science and Technology, Federal Industrial Research Organisation (FIRO), Lagos.

Park, Y.W., 1994. Hypoallergic and therapeutic significance of goat milk. Small Rum. Res. 14, 151-158.

Park, Y.W., Chukwu, H.I., 1989. Trace minerals and AngloNubian breeds during the first five months of lactation. J. Food Comp. Anal. 2, 161-167.

Prakash, S., Jenness, R., 1968. The composition and characteristics of goat milk. Dairy Sci. Abstr. 30, 67-68.

Preston, T.R., 1982. Nutritional limitations associated with the feeding of tropical forages. J. Anim. Sci. 54, 877-884.

Ramos, N.M.M., Juarez, M., 1981. The Composition of Ewes' and Goats' Milk. Document 140. International Dairy Federation Bulletin.

Sachdeva, K.K., Sengar, O.P.S., Singh, S.N., Lindahl, I.L., 1974. Studies on goats. 2. Effect of plane of nutrition on milk production and composition. Milchwissenschaft 29, 471-475.

SAS, 1987. Statistical Analysis System. SAS Institute, Cary, NC.

Sibanda, L.M., Ndlovu, L.R., Bryant, M.J., 1999. Effects of a low plane nutrition during pregnancy and lactation on the performance of Matebele does and their kids. Small Rum. Res. 32, 243-250.

Silva, A.T., Orskov, E.R., 1988. The effect of five different supplements on the degradation of straw in sheep given untreated barley straw. Anim. Feed Sci. Technol. 19, 289-298.

Swan, H., Lamming, G.E., 1967. Studies on the nutrition of ruminants. II. The effect of crude fibre in maize-based rations on the carcass composition of Friesian steers. Anim. Prod. 9, 203-208.

Van der Horst, R.L., 1976. Foods of infants allergic to cow milk. South African Med. J. 5, 927-932. 